\title{
Dynamic impact of Gold Prices, Oil Prices and Exchange Rate on Stock Market Performance: A Case of Pakistan's Stock Exchange (KSE 100 Index)
}

\author{
Asif Ali a , Muhammad Kamran Khan ${ }^{\text {b }}$, Hamid Ullah ${ }^{\text {c }}$ \\ ${ }^{a}$ Islamia College Peshawar, Pakistan \\ Email: asifalisafi53@gmail.com \\ b Bacha Khan University, Pakistan \\ Email: drkamrankhan@bkuc.edu.pk \\ ${ }^{\mathrm{c}}$ Islamia College Peshawar, Pakistan \\ Email: hamidullah@icp.edu.pk
}

\begin{tabular}{l}
\hline ARTICLE DETAILS \\
\hline History: \\
Accepted 25 Feb 2021 \\
Available Online March 2021 \\
\hline Keywords: \\
Gold Prices, Oi Prices, Securities \\
Market Performance, Foreign \\
Exchange Rate \\
\hline JEL Classification: \\
E31, E64, F31 \\
\hline
\end{tabular}

DOI: $10.47067 /$ reads.v7i1.309

\begin{abstract}
Currently emerging markets are passing through economic turmoil due to considerable increases in the prices of oil and gold with significant variation in the foreign exchange market. All the macroeconomic variables are touching the highest value which was never occurred in the history of Pakistan. Taking advantages of the current situation the study has examined the impact of gold prices, oil prices and exchange rate on stock market performance. For this purpose, the study has used daily data of these macroeconomic variables for the period of 2003 to 2018. By using time series data analysis, it reveals that there is no cointegration or long-term relation among these variables; however, the vector autoregressive model showed significant short-term relation among the securities market performance, foreign exchange rate, prices of oil and gold. The analysis also suggests that significant changes in the prices of oil, foreign exchange rates and the prices of gold have a negative lagged effect on the performance of the stock market.
\end{abstract}

(C) 2021 The authors. Published by SPCRD Global Publishing. This is an open access article under the Creative Commons Attribution-

NonCommercial 4.0

Corresponding author's email address: drkamrankhan@bkuc.edu.pk

\section{Introduction}

Investors are interested in that sections of the economy, which give them high return with little volatility. They are also interested in that sectors where a consistent upward trend is found in the prices of securities market. By this way, they can exploit the upward trends in prices for profit and wealth maximization through several available opportunities for investment. It includes investment in the equity market, commodity market, and debt market. For equity and debt markets, the main financial instruments are shares and bonds respectively. While in commodity markets gold and crude oil futures are the most valuable commodities. Globally Trade-in foreign exchange market is deemed to be the biggest financial market. The mentioned markets contribute substantially in country's economic 


\section{Review of Economics and Development Studies, Vol. 7 (1) 2021, 1-12}

development process. Therefore, the association between prices of gold, oil, foreign exchange rates and stock returns (KSE10o PSX) has been analyzed. The central idea of the study is to analyze securities market and how the volatility of these macro-economic variables affect securities market behaviour and vice versa.

The securities market is considered as a key instrument for both economic and industrial development of a country. The market is very sensitive, so it is necessary to consider all the factors influencing securities market. The securities market index indicates economic strength of a country. Variation in the market index is a serious concern for both the government and investors. Pakistan stock exchange is one of the leading stock markets in the world. 1Therefore, it has attracted investors from worldwide.

Gold is a valuable commodity, contributes significantly to the economic development of a country. Vitality of gold for an economy has several reasons (Bhunia, 2013)). It is kept as a reserve on the back of currency; used as a medium of exchange; a secure source of investment and many more. The value of gold is determined in the international market, which has been traded at the same price globally. That is why investors considered gold as a safe haven in the period of recession Bhunia and Das (2012). Economic theory suggests that during a crisis, the prices of equity falls while the price of gold rises. So, the investors tend to invest in gold in order to hedge the risk of inflation. By this way there is a downward trend the stock market even in some cases the market has been crushed. Several studies suggest that at the time crisis stock market return is low so investors buy gold, while in prosperity the stock market return is high, they sell gold and buy stocks Baur and Lucey (2010). Currently, Pakistan economic indicators are unpredictable, gold touches the highest value which was never occurred in history. Along with this due to poor economic policies, the stock market return is in a downward spiral. Therefore, investors feel reluctant to invest in stocks. As a result, the demand for gold has been increased.2

Today's world economy largely depends on oil. Due to industrialization and expansion of the transportation industry, the demand for oil is multiplying. Since the operation of industries largely depends on oil, therefore, a little variation in oil price may affect stock market returns (Ciner, Gurdgiev \& Lucey, 2013)). However, this fluctuation depends upon the nature of the economy that either the country is importer or exporter of oil. Currently, in Pakistan, the prices of oil are on the rise, which has adversely affected industries returns Kilian and Park (2009). It is because the prices of factors of production largely depend on oil prices. A small increase in prices of oil brings a hike in the prices of goods and services. That is why it may affect the performance of industries and securities market at large.

Foreign exchange rate is one of the key macro-economic variables. It is extremely important for foreign trade and overall economic development. Fluctuation in the foreign exchange rate can alter both securities market returns and its trade volume (Kakhani, 2012; \& Rahman, 2011). Currently, in Pakistan, fluctuation in exchange rate is a serious concern for the government, policymakers, and investors as well. In this situation forecasting of exchange rate seems difficult. Government is trying to adopt certain measures to bring stability in exchange rate in order to boost economic activities. Studies indicate a positive relationship in securities market return and exchange rate which has been reflected

1 Karachi stock exchange ranked third in the world and first in Asia in 2014 as per Daily times Pakistan (2015). 2 According to The Express Tribune (2016) the country falls in the list of top ten consumers of gold. 


\section{Review of Economics and Development Studies, Vol. 7 (1) 2021, 1-12}

from investors' behavior (Abbas, 2010). They use exchange rate information for investing in stock market. When securities returns are maximum, they dispose their assets in foreign market and acquire home assets. The exchange of assets increases demand for home currency in foreign exchange market by exerting upward pressure on its prices. Apart from these, there are several other reasons as well which give impetuous to determination of the foreign exchange.

The current study has posed various questions that is there any long term and short run effect of the oil prices, gold prices and exchange rate on stock market performance? The main objective of the study is to examine the long term and short run effect of the oil prices, gold prices and exchange rate on the stock market performance. This study will contribute significantly to policy makers and investors. It is due to the fact that from the last few years Pakistan's macro-economic variables show high volatility which creates chaos in the country. In this situation, it is difficult to make a rational economic decision. Now it is high time to study the interdependent association among these variables. This study is mainly motivated by the current variation in prices of gold, oil and foreign exchange rate associated with volatility and downturn in the securities market. The paper contains five sections. Section two is about review of literature, section three contains data and methodology, section four covers findings and interpretation and the last section is about conclusion and references.

\section{Literature Review}

Earlier studies had focused on analyzing the association in-between foreign exchange market and securities market. Their results revealed that in the presence of these two approaches that are 'good market approach' and portfolio balance approach' (Dornbusch \& Fischer, 1980) could better explain the relationship between the markets. The former approach suggests that variation in exchange rate brings variation in firm's earnings. It is happened either by foreign trade or borrowing from international market which affects the prices of stock market. Therefore, while considering exchange rate is a leading variable, an inverse linkage has been existed in between the two markets. The latter approach tells that a progressive market can attract foreign investors which rise the demand for domestic currency. Thus, while considering stock market as a leading variable, there is a positive relation between the above-mentioned markets.

In addition, the study of Kakhani (2012) and Rahman (2011) revealed that rather than a causal relationship, there exists a positive connection in foreign exchange market and securities market. The study of Abbas (2010) showed the non-existence of long-run relation in-between foreign exchange market and securities market. However, short-term causal relationship exists between the markets found by Murinde (1997) and Samanta (2003). Olugbenga (2012) also conducted a study on Nigeria securities market and found a significant relationship between exchange rate and securities market.

He further stated that changes in foreign exchange market would be predicted for securities market. Similarly, Kang and Yoon (2013) also studied the marriage between foreign exchange market and securities markets for the period of 1990 to 2009 in South Korea. Their study revealed a causal relationship between the two markets.

According to the findings of Apte (2001) and Morales (2008) a dynamic association exists in the markets by using generalized autoregressive conditionally heteroskedastic (GARCH) models. It also confirms that the variation is spread over the markets. Besides the exchange rate, stock market is also sensitive to variation in oil and gold prices. Few studies were conducted on showing the relation in security market and oil prices. Normally these variables are taking collectively with other variables such as gold, interest rate and foreign exchange rate, etc. It is evident that the prices of oil affect both cost 


\section{Review of Economics and Development Studies, Vol. 7 (1) 2021, 1-12}

and profit of a company which brings volatility in security prices. Faff and Brailsford (1999) studied that the impact of prices of oil on the security oil prices, gas and other revised industries is positive, while its impact become negative on transportation and paper and packaging industries. Previous studies on the same topic reflect an inter-dependent relation might exist between the two variables (prices of oil and prices of securities). For example, Basher and Sadorsky (2006) found the influence of prices of oil on securities return.

Kilian et al., (2009) also analyzed the relationship between prices of oil and securities market and found that an increase in the prices of oil negatively affect securities market. Likewise, Oberndorfer (2009) examined the effect of oil prices on securities return for the era of 2002-07 by applying both the models i.e. ARCH and GARCH. He expressed that increase in the prices of oil has an adverse effect on European securities market returns. All of these studies acknowledge the impact of oil prices on securities market returns.

Further, Gaur and Bansal (2010) concluded that, during crisis as securities market falls it tends to increase prices of gold. Same result has been explored by Le and Chang (2012) that securities market is act as an agent for rising prices of gold. The work of Chohan (2011) also suggested a negative association in prices of gold and securities prices. Bhunia (2013) studied the linkage between domestic prices of gold and security return, by applying Granger test. His study showed a bidirectional causality between the of prices of gold and security price return. However, Kaliyamoorthy and Parithi (2010) found no linkage in security market indices and gold prices. As the indices of security market increases, gold price also increases, but the increase in prices of gold is not as result of securities market. However, gold is providing protection in the time of financial crisis as suggested by Dirk and Baur (2010). Study of Arouri (2015) also revealed that the impact of the volatility of gold prices on China's securities market return is significant by using VAR-GARCH model. Gilmore et al., (20o9) concluded that both gold and securities effect each other in short term. It is evident from the above studies that during financial crisis the prices of securities fall and the prices of gold rises, thus gold provides protection to investors during crisis.

Multiple studies had been conducted in order to explore the relationship between oil and gold. For instance, Melvin and Sultan (1990) found that fluctuation in prices of oil and detrimental political condition determine prices of gold. Zhang and Wei (2010) examined cointegration and causality for oil and gold prices for the period of 2000-08. They found significantly positive relation between the variables. The finding of Wang and Chueh (2013) is consistent with them. In addition, the study of Simakova (2011) showed a long-term association in the prices of oil and gold. The exchange of gold for crude oil was first emerged in Middle East. Both oil and gold have an association with exchange rate. Fluctuation in exchange rate may bring changes in the prices of internationally traded goods. Sadorsky (2000) and Akram (2009) analyzed the impact of foreign exchange rate on oil and other commodities. Similarly, Fratzscher et al., (2014) investigated a bidirectional causal relation between the variables.

Likewise, the study of Sjaastad (2008) suggested the influence of exchange rate on gold prices. Mishra and Debasish (2016) examined a study in India by using the GARCH model. They found that the rise in prices of oil might decrease the value of Indian rupee presenting an interdependent relationship between them. Researchers like Harri, Nalley, and Hudson (2009) analyzed that foreign exchange rate brings changes in the prices of oil and other commodities. Hammoudeh, Chen, and Fattouh (2010) also suggested a long-run association in-between prices of gold and crude oil. Beckmann and Czudaj (2013) analyzed the long-term and short-term connection in gold and crude oil and found that the long-run relationship is visible and gold price has significant impact on the economy of USA. Same result is also 


\section{Review of Economics and Development Studies, Vol. 7 (1) 2021, 1-12}

found by Lee, Huang, and Yang (2012) that the relation between gold and prices of crude oil is significant. Reboredo (2013) used copula approach and analyzed significantly positive link between the variables. He suggested that gold could not be hedged against the volatility of oil price. Similarly, Wang and Chueh (2013) also showed positive connection in gold and oil prices. From these studies it can be stated that a linkage is exist between the variables.

Numerous studies have also been conducted to further explain the relationship between all the four variables like oil, gold, foreign exchange rate, and securities market. Ciner, Gurdgiev, and Lucey (2013) analyzed the association of return with bonds, gold, oil, stocks and foreign exchange rate. They concluded that gold is considered as a safe haven against foreign exchange rates. Moreover, the causal association among oil, gold, foreign exchange rate and stock is also investigated by Christner and Dicle (2012), Kumar (2011) and Basher and Sadorsky (2006) and found that the prices of oil had an adverse effect on both security market and foreign exchange rate. Changes in other variables lead to changes in foreign exchange rate to a great extent while the securities market has the least impact on foreign exchange rate. Mu-Lan, Ching-Ping, and Tzu-Ying (2010) and Samanta and Zadeh (2012) also examined the co-movement among gold, oil, exchange rate, and stock markets and found a long-run relation among the above-mentioned markets. The work of Joshi (2012) indicated that the relation of gold with crude oil, foreign exchange rate, and securities market return is significant while, in some cases the relation become inverse. Kim and Dilts (2011) also found same result.

Numerous studies have been conducted in the same field showing mixed result among the mentioned variables. There are various reasons for the mixed result. So, by using the Granger causality test can validate the linkage between the above-mentioned variables.

\section{Methodology}

This section includes data collection, sample size and different types of statistical tests used for the analysis of data.

\subsection{Nature of Study}

This study has examined the relationship of the gold price, exchange rate and oil prices on the stock market performance. The study is applied in nature as it has tested the relationship empirically by following a research design of the explanatory study and provide implications for the policy makers and managers.

\subsection{Data Collection}

Secondary data has been collected from different sources. The data includes a daily record of use KSE100 returns, gold prices, oil prices and foreign exchange rate for a period of 2003 to 2018 . The data of oil prices exchange rate and gold prices data is collected from the website of macrotrends.net, whereas, KSE-100 index data is collected from the ksestock.com.3 In this study, descriptive statistics have been applied to find out the mean, median, standard deviation and skewness of data. Augmented Dickey-Fuller Test has been used for data stationarity. Johansen Co-integration test is used for long-run association among the variables. Granger Causality test is used for the relationship of Lead and Lag. The main variables of the study are KSE100 returns, prices of oil, prices of gold, and foreign exchange rate.

\section{Analysis and Findings}

There are various statistical tools are used for testing the dynamic relationship among the stock 
prices, oil prices, gold prices and foreign exchange rate. The empirical results of the different tests used in this study are mentioned below.

The results of Table-1 show that KSE has a higher return than gold, exchange rate, and oil. KSE also reflects high variation (high standard deviation) in returns as compared to other variables. The nature of all these variables are asymmetrical except one variable (gold) which is negatively skewed, and remaining variables are positively skewed.

\section{Table 1 : Descriptive Statistics}

\begin{tabular}{|l|l|l|l|l|}
\hline Variables & EXRATE & GOLD & KSE & OIL \\
\hline Mean & 84.995 & 1029.754 & 19389.01 & 68.321 \\
\hline Std. Dev. & 20.876 & 407.406 & 13739.73 & 24.112 \\
\hline Skewness & 0.112 & -0.229 & 0.750 & 0.333 \\
\hline Kurtosis & 2.012 & 1.961 & 2.151 & 2.332 \\
\hline Jarque-Bera & 163.46 & 205.34 & 473.48 & 141.96 \\
\hline Probability & 0.000 & 0.000 & 0.000 & 0.000 \\
\hline
\end{tabular}

Before further process first these four-time series i.e. crude oil, gold price, foreign exchange rate, and KSE should be tested for the Stationarity and Non-Stationarity. The Augmented Dickey-fuller test has been used for this purpose. The results are shown in Table-2. It shows that at level the Taucalculated values of the tests are less than Tau-tabulated values so the null hypothesis (Ho) is accepted i.e. the data of all the variables is non stationary, while at level of first difference the Tau calculated values are greater than the Tau-tabulated values so the data is stationary at $5 \%$ level of significance. In addition, as the data of all the variables are stationary at first difference, thus it fulfills the basic requirement of further testing of cointegration, therefore Johansen's Co-integration test has been used to analyze the data.

Table 2: Augmented Dickey Fuller Tests

\begin{tabular}{|l|c|c|l|}
\hline SN & Time Series & \multicolumn{2}{|c|}{ Augmented Dickey Fuller Tests } \\
\hline & & At level & First difference \\
\hline 1 & Crude Oil & -2.125 & $-65.486^{*}$ \\
\hline 2 & Gold Price & -1.599 & $-61.888^{*}$ \\
\hline 3 & Exchange Rate & 2.262 & $-60.181^{*}$ \\
\hline 4 & KSE & 0.319 & $-52.192^{*}$ \\
\hline
\end{tabular}

* Significance at $5 \%$ level of significance

\subsection{Selection of Optimal Lag}

In order to use the VAR model, the selection of optimal lagged term is the most important aspect of VAR model. Therefore, the current study has used the five basic criteria identified by the Lutkepohl (1993) for the selection of lag; i.e. Sequential modified LR test statistics (LR), Final prediction error (FPE), Akaike information criterion (AIC), Schwarz criterion (SC) and Hannan-Quinn information criterion (HQ). The smallest value of these five criteria shows the optimal lag length. So, on the basis of results, seven lags have been selected for the model. The whole results are given in Table-3. 
Table 3 VAR Lag Order Selection Criteria

Endogenous variables: KSE OIL GOLD EXRATE

Included observations: 3816

\begin{tabular}{|c|c|c|c|c|c|c|}
\hline Lag & Log L & LR & FPE & AIC & SC & HQ \\
\hline $\mathbf{0}$ & -99150.096 & NA & 4.36 & 51.967 & 51.974 & 51.969 \\
\hline $\mathbf{1}$ & -49535.717 & 99098.74 & 2237993. & 25.972 & 26.005 & 25.984 \\
\hline $\mathbf{2}$ & -49414.339 & 242.182 & 2117741. & 25.917 & $25.976^{*}$ & $25.938^{*}$ \\
\hline $\mathbf{3}$ & -49404.29 & 20.140 & 2124295. & 25.920 & 26.005 & 25.950 \\
\hline $\mathbf{4}$ & -49389.507 & 29.324 & 2125712. & 25.921 & 26.032 & 25.960 \\
\hline $\mathbf{5}$ & -49357.173 & 64.310 & 2107593. & 25.912 & 26.050 & 25.961 \\
\hline $\mathbf{6}$ & -49345.980 & 22.243 & 2112910. & 25.915 & 26.078 & 25.973 \\
\hline $\mathbf{7}$ & -49325.012 & $41.614^{*}$ & $2107416 . *$ & $25.912^{*}$ & 26.102 & 25.979 \\
\hline $\mathbf{8}$ & -49312.578 & 24.654 & 2111360. & 25.914 & 26.130 & 25.991 \\
\hline * indicates lag order selected by the criterion & \\
\hline \\
LR: sequential modified LR test statistic (each test at 5\% level) \\
\hline FPE: Final prediction error \\
AIC: Akaike information criterion \\
SC: Schwarz information criterion \\
HQ: Hannan Quinn information criterion \\
\hline
\end{tabular}

The result of the Unrestricted Cointegration Rank Test (Trace) is given in Table-4. Johansen's Cointegration test is used for analyzing long term relation among different variables. It show the Trace value is less than the critical values (i.e. $5 \%$ ) so we accept the null hypothesis i.e. that there exists no co-integration or long-run relation among the variables.

Table 4 Unrestricted Cointegration Rank Test (Trace)

\begin{tabular}{|l|l|l|l|l|}
\hline Time Series & $\begin{array}{l}\text { Trace } \\
\text { Statistic }\end{array}$ & Critical Value & Prob. $^{* *}$ & Remarks \\
\hline $\begin{array}{l}\text { Crude oil, Gold price, KSE, Exchange } \\
\text { rate }\end{array}$ & 36.046 & 47.856 & 0.394 & No Cointegration \\
\hline
\end{tabular}

Table- 5 shows the results of Unrestricted Cointegration Rank Test (Maximum Eigenvalue). Here the Max-Eigen values are less than the 0.05 Critical values, so the null hypothesis is accepted. It means that there is no co-integration or long-run relation among the variables. Hence it is evident from both of the tests that there is no long-run relationship among the variables. A short run relationship is expected among the variables.

Table 5 Unrestricted Cointegration Rank Test (Maximum Eigenvalue)

\begin{tabular}{|l|l|l|l|l|}
\hline Time Series & Max Eigenvalue & Critical Value & Prob.** & Remarks \\
\hline $\begin{array}{l}\text { Crude Oil, Gold Price, } \\
\text { Exchange Rate, KSE }\end{array}$ & 25.846 & & & No cointegration \\
\hline
\end{tabular}

Table- 6 shows the results of the VAR. The first model shows that at first lag of KSE is a significant effect on KSE, while the second lag has a negative significant effect on KSE. Further, in case 


\section{Review of Economics and Development Studies, Vol. 7 (1) 2021, 1-12}

of oil at first lag, it has a positive significant effect but at second lag the effect becomes negative thus increase in oil prices will negatively affect the stock market after two days' change in oil prices. However, gold has a negative insignificant effect on KSE at first lag, while in the second lag the effect becomes positively insignificant. In case of exchange rate, it has a positive insignificant effect on KSE at first lag, while the effect becomes negatively insignificant at a second lag.

Table 6 Vector Auto regression Estimates

Included observations: 3822 after adjustments

Standard errors in ( ) \& t-statistics in [ ]

\begin{tabular}{|c|c|c|c|c|}
\hline VARIABLES & KSE & OIL & GOLD & EXRATE \\
\hline \multirow[t]{3}{*}{ KSE(-1) } & 1.165 & 4.906 & 0.0004 & -0.001 \\
\hline & $(0.015)$ & (0.0001) & $(0.0008)$ & $(2.061)$ \\
\hline & {$[73.024]$} & {$[0.047]$} & {$[0.515]$} & {$[-6.035]$} \\
\hline \multirow[t]{3}{*}{ KSE(-2) } & -0.166 & -1.775 & -0.0004 & 0.001 \\
\hline & (0.017) & $(0.0001)$ & $(0.0008)$ & $(2.061)$ \\
\hline & {$[-10.441]$} & {$[-0.017]$} & {$[-0.556]$} & [6.041] \\
\hline \multirow[t]{3}{*}{ OIL(-1) } & 6.085 & 0.935 & 1.047 & 0.002 \\
\hline & $(2.525)$ & $(0.016)$ & $(0.132)$ & $(0.003)$ \\
\hline & {$[2.407]$} & [ 57.007] & [ 7.881] & [ 0.640$]$ \\
\hline \multirow[t]{3}{*}{ OIL(-2) } & -6.281 & 0.059 & -1.050 & -0.059 \\
\hline & $(2.523)$ & $(0.016)$ & $(0.132)$ & $(0.007)$ \\
\hline & {$[-2.485]$} & [ 3.657] & {$[-7.905]$} & {$[-0.418]$} \\
\hline \multirow[t]{3}{*}{ GOLD(-1) } & -0.235 & 0.002 & 0.976 & -0.006 \\
\hline & (0.3098) & $(0.002)$ & (0.016) & $(0.004)$ \\
\hline & {$[-0.797]$} & [ 1.079] & [ 59.853] & {$[-1.517]$} \\
\hline \multirow[t]{3}{*}{ GOLD(-2) } & 0.245 & -0.001 & 0.022 & 0.005 \\
\hline & (0.309) & $(0.000)$ & $(0.016)$ & $(0.004)$ \\
\hline & [ o.793] & {$[-0.889]$} & [ 1.380$]$ & [ 1.391$]$ \\
\hline \multirow[t]{3}{*}{ EXRATE(-1) } & 2.844 & 0.012 & 0.468 & 1.020 \\
\hline & $(12.485)$ & $(0.081)$ & (0.657) & $(0.016)$ \\
\hline & {$[0.227]$} & [ 0.154$]$ & [ 0.719] & [63.279] \\
\hline \multirow[t]{3}{*}{ EXRATE(-2) } & -2.309 & -0.021 & -0.438 & -0.019 \\
\hline & $(12.511)$ & $(0.081)$ & $(0.658)$ & $(0.016)$ \\
\hline & {$[-0.184]$} & {$[-0.260]$} & {$[-0.665]$} & {$[-1.183]$} \\
\hline \multirow[t]{3}{*}{ C } & -14.213 & 0.583 & -0.139 & -0.071 \\
\hline & $(27.314)$ & (0.177) & $(1.462)$ & (0.035) \\
\hline & {$[-0.520]$} & {$[3.283]$} & {$[-0.097]$} & {$[-2.128]$} \\
\hline
\end{tabular}

However, Co-integration test does not show the lead-lag of the data. Therefore, Granger Causality test is applied to find the lead-lag relationship among the variables. Hence, Granger causality actually measures whether current and past values of 'Yt' help to forecast future values of 'Zt'. Results of Granger Causality test are given in Table-7. It highlight that oil does not granger cause KSE and exchange rate; KSE does not granger cause oil and gold; gold does not granger cause oil, KSE and exchange rate and exchange rate does not granger cause oil, KSE and gold as well, because the value of calculated F-statistic is less than the value of tabulated F-statistic, therefore the null hypothesis is 
Review of Economics and Development Studies, Vol. 7 (1) 2021, 1-12

accepted. However, KSE does granger cause exchange rate and, oil does granger cause gold, therefore the null hypothesis is rejected.

Table 7. Pairwise Granger Causality Tests

\begin{tabular}{|l|c|l|l|}
\hline Null Hypothesis & No of Observations & F-Statistic & Prob. \\
\hline OIL does not Granger Cause KSE & 3822 & 2.685 & 0.068 \\
\hline KSE does not Granger Cause OIL & 3822 & 0.422 & 0.655 \\
\hline GOLD does not Granger Cause KSE & & 0.689 & 0.501 \\
\hline KSE does not Granger Cause GOLD & 3822 & 0.291 & 0.746 \\
\hline Exchange Rate does not Granger Cause KSE & 1.333 & 0.263 \\
\hline KSE does not Granger Cause Exchange Rate & 18.308 & 1.220 \\
\hline GOLD does not Granger Cause OIL & 3822 & 0.620 & 0.537 \\
\hline OIL does not Granger Cause GOLD & 31.048 & 4.209 \\
\hline Exchange Rate does not Granger Cause OIL & 3822 & 0.714 & 0.498 \\
\hline OIL does not Granger Cause Exchange Rate & & 1.919 & 0.149 \\
\hline Exchange Rate does not Granger Cause GOLD & 3822 & 0.219 & 0.808 \\
\hline GOLD does not Granger Cause Exchange Rate & & 0.978 & 0.378 \\
\hline
\end{tabular}

\section{Discussion}

Globally various studies had been conducted on this topic. Our study is different from the prior studies in terms of context and period of time. However, the results of current study are consistent with the prior studies up to a greater extend. Like the results of Joshi (2012) and Sujit and Kumar (2011) are allied with this study. They found long run relation among the mentioned variables. Similarly, Monjazeb and Shakerian (2014) and Phoong, Ismaid and Sek (2013) also revealed that there is a mutual link between securities market, gold and crude oil. Same results have also been found in current study. Moreover, Toraman, Basarir and Bayramoglu (2011); Malliaris and Malliaris (2013) and Kim and Dilts (2011) also found the long run relationship between these variables which are also consistent with current study. In addition, Lee, Huang and Yang (2012); Beckmann and Czudaj (2013); Tully and Lucey (2007) and Choudhary et al (2014) also found the long-run association between these variables. Hence it has been confirmed that the findings of this article are alike with prior research work on this topic though the span of time and market were different.

\section{Conclusions and Future Directions}

Currently, the economy of Pakistan is telling a new story. There is a considerable hike in the prices of oil and gold with significant variation in the exchange rate which was never occurred in the history of Pakistan. This unexpected variation in the prices of oil, gold, and foreign exchange make it difficult for the analysis to forecast. As a result, these variables may affect one another which make the business environment more turbulent for investors. Therefore, it is required to address the issue and analyze the interdependent relationship among these variables. For this purpose, this study considered daily time-series data from January 2003 to December 2018. The study used time series data analysis and found that there is no co-integration or long-run relationship among these variables, however, the vector autoregressive model showed significant short-run relationship among the securities market performance, foreign exchange rate, prices of oil and gold. The results showed that significant changes in prices of oil, exchange rates, and prices of gold have a negative lagged effect on the securities market performance. Granger casualty test shows that oil does not granger cause KSE and exchange rate; KSE does not granger cause oil and gold; gold does not granger cause oil, KSE and foreign exchange rate and 


\section{Review of Economics and Development Studies, Vol. 7 (1) 2021, 1-12}

the exchange rate does not granger cause oil, KSE and gold as well. However, KSE does granger cause foreign exchange rate and oil do granger cause gold.

This study is very much helpful for investors either to invest in financial assets or real assets. It also provides a guideline to the policymakers and analyst to consider these macroeconomic variables for the best interest of all stakeholders. In the future, this study will also be conducted by using different models with different macroeconomic variables. Further, it can also be studied across the country for comparative analysis.

\section{References}

Akram, Q.F. (2009). “Commodity prices, interest rates and the dollar”, Energy Economics, Vol. 31 No. 6, pp. 838-851

Apte, P. G. (2001). The interrelationship between the stock markets and the foreign exchange

$\begin{array}{lllll}\text { market. } & \text { Retrieved } & 26 & \text { August } & \text { fo15, }\end{array}$ http://papers.ssrn.com/sol3/papers.cfm?abstract_id=2161245

Arouri, M. E., Lahiani, A., Nguyen, D. K. (2015). World Gold Prices and Stock Returns in China: Insights for Hedging and Diversification Strategies. Economic Modelling 44, 273-282.

Basher, S. A., Sadorsky P. (2006). Oil price risk and emerging stock markets. Global Finance Journal 17, 224-251.

Baur, D. G., \& Lucey, B. M. (2010). Is gold a hedge or a safe haven? An analysis of stocks, bonds and gold. Financial Review, 45(2), 217-229.

Beckmann, J., Czudaj, R. (2013). Is there a homogeneous causality pattern between oil prices and currencies of oil importers and exporters? Energy Economics 40, 665-678.

Bhunia, D. A. \& Das, M. A. (2012). Association between Gold Prices and Stock Market Returns: Empirical Evidence from Nse. Journal of Exclusive Management Science, Vol 1, Issue 2, pp. $1-7$.

Chohan, H. S. (2011). Impact of gold prices on stock echange: A case study of Pakistan. Retrieved 26 August 2015, from http://saicon2011.ciitlahore.edu.pk/economics/1038.pdf.

Christner, R., \& Dicle, M. F. (2012). Casual or causal relationships between US Dollar, gold, oil and equity markets. Annual Conference on Innovations in Business and Management, London, UK.

Ciner, C., Gurdgiev, C., \& Lucey, B. M. (2013). Hedges and safe havens: An examination of stocks, bonds, gold, oil and exchange rates. International Review of Financial Analysis, 29(September), 202-2011.

Dirk, G. \& Baur, T. K. (2010). Is gold a safe haven? International evidence. Journal of Banking and Finance, 34(8), 1886-1898.

Dornbusch, R., \& Fischer, S. (1980). Exchange rates and the current account. The American Economic Review, 70(5), 960-971.

Faff, R. W, \& Brailsford, T. J. (1999). Oil price risk and the Australian stock market. Journal of Energy Finance and Development, 4(1), 69-87.

Fratzscher, M., Schneider, D., Robays, I.V. (2014). Oil prices, exchange rates and asset prices, ECB Working Paper 1689. 


\section{Review of Economics and Development Studies, Vol. 7 (1) 2021, 1-12}

Gaur, A., Bansal, M., 2010. A comparative study of gold price movements in indian and global markets. Indian Journal of Finance 4, 32-37.

Gilmore, C.G., McManus, M.G., Sharma, R., Tezel, A. (2009). The dynamics of gold prices, gold mining stock prices and stock market prices comovements. Research in Applied Economics $1,1-19$.

Hammoudeh, S., Chen, L. H., \& Fattouh, B. (2010). Asymmetric adjustments in oil and metals markets. The Energy Journal (Cambridge, Mass.), 31(4), 183-203. doi:10.5547/ISSNo1956574-EJ-Vol31-No4-9.

Harri, A., Nalley, L., \& Hudson, D. (2009). The relationship between oil, exchange rates, and commodity prices. Journal of Agricultural and Applied Economics, 41(2), 501-510.

Joshi, V. K. (2012). Impact of Fluctuation: Stock/ Forex /Crude Oil on Gold. SCMS Journal of Indian Management, 9(4), 96-114.

Kakhani, D. G. (2012). Relationship between stock market and foreign exchange market in India: An empirical study. Pacific Business Review International, 5(5), 66-71.

Kaliyamoorthy, D. S. \& Parithi, M. S. (2012). Relationship of Gold Market and Stock Market: An Analysis. International Journal of Business and Management Tomorrow, Vol. 2, No. 6, June, pp. 1-6.

Kang, S.H. and Yoon, S.M. (2013). "Revisited return and volatility spillover effect in Korea”, Korea and the World Economy, Vol. 14 No. 1, pp. 121-145.

Kilian, L., \& Park, C. (2009). The impact of oil price shocks on the US stock market*. International Economic Review, 50(4), 1267-1287.

Kim, M. H., \& Dilts, D. A. (2011). The relationship of the value of the dollar, and the prices of gold and oil: Atale of asset risk. Economic Bulletin, 31(2), 1151-1162.

Kumar, K. S. (2011). Study on dynamic relationship among gold price, oil price, exchange rate and stock market returns. International Journal of Applied Business and Economic Research, $9(2), 145-165$.

Le, T.H., Chang, Y. (2012). Oil price shocks and gold returns. International Economics 131, 71-104. Melvin, M., Sultan, J. (1990). South african political unrest, oil prices, and the time varying risk premium in the gold futures market. Journal of Futures Markets 10, 103-111.

Mishra, S. (2017). Analysis of Volatility Spill Over between Oil Price and Exchange Rate in India: GARCH Approach. SSRN Electronic Journal, January. https://doi.org/10.2139/ssrn.2892670

Morales, L. (2008). Volatility spillovers between equity and currency markets: Evidence from major Latin American countries. Latin American Journal of Economics, 45(132), 185-215.

Mu-Lan, W., Ching-Ping, W., \& Tzu-Ying, H. (2010). Relationships among oil price, gold price, exchange rate and international stock markets. International Research Journal of Finance and Economics 47, 82-91.

Murinde, I. S. (1997). Exchange rate and stock price interactions in emerging financial markets: Evidence on India, Korea, Pakistan and the Philippines. Applied Financial Economics, 7(1), 25-35.

Oberndorfer, U., (2009). Energy prices, volatility, and the stock market: evidence from the Eurozone. Energy Policy 37, 5787-5795.

Olugbenga, A.A. (2012). Exchange rate volatility and stock market behaviour: The Nigerian 
experience. European Journal of Business and Management 4, 31-39

Rahman, Q. Z. (2011). The causality between stock market and foreign exchange market of Pakistan. Interdisciplinary Journal of Contemporary Research in Business, 3(1), 906-919.

Reboredo, J.C. (2013). Is gold a hedge or safe haven against oil price movements? Resources Policy $38,130-137$.

Samanta, G. C. (2003). Dynamic relation between exchange rate and stock prices-A case for India. Retrieved 26 August 2016, from http://nse-india.com/content/press/feb2003c.pdf.

Sadorsky, P., (1999). Oil price shocks and stock market activity. Energy Economics 21, 449-469.

Samanta, S. K., \& Zadeh, A. H. M. (2012). Co-movements of oil, gold, the US Dollar, and stocks. Modern Economy, 3(1), 111-117.

Simakova, J. (2011). Analysis of the Relationship between oil and gold prices. Retrieved 1 January 2014, from www.opf.slu.cz/kfi/icfb/proc2011/pdf/58_Simakova.pdf.

Sjaastad, L. A. (2008). The price of gold and the exchange rates: Once again. Resource Policy, 33(2), 118-124.

Wang, Y.S., Chueh, Y.L. (2013). Dynamic transmission effects between the interest rate, the US dollar, and gold and crude oil prices. Economic Modelling 30, 792-79

Zhang, Y., \& Wei, Y. (2010). The crude oil market and the gold market: evidence for cointegration, causality and price discovery. Resources Policy, 35, 168-177.

Web sites:

https://www.psx.com.pk.

https://www.dailyfx.com/crude-oil

https://goldprice.org/gold-price-pakistan.html

https://datacatalog.worldbank.org/dataset/world-development-indicators 